\title{
Technological capacity-building in unstable settings: Manufacturing firms in Argentina and Brazil
}

\author{
Anabel Marin, Lilia Stubrin and Maria Amelia Gibbons
}

ABSTRACT

From the 1970s onward, the macroeconomic context in Argentina and Brazil was characterized by drastic economic changes and instability. Numerous studies have documented the generally negative effect of this environment on the innovation capacities of the manufacturing sector. This paper, however, analyses the possible emergence of new innovation capacities in the period, bringing two important phenomena to light. First, a quite substantial number of firms, even in unstable settings, redoubled their innovation efforts. Second, these firms are mainly found in a small group of sectors associated with the countries' static advantages or in sectors favoured by specific sectoral regimes. The findings, although exploratory, are a contribution to the debate on the development of innovative capacities in unstable macroeconomic contexts and the ability of sectors associated with the two countries' static advantages to generate spaces of innovation and value creation.

KEYWORDS

JEL CLASSIFICATION

AUTHORS
Industry, manufactures, economic conditions, technological innovations, research and development, statistical data, Argentina, Brazil

$\mathrm{O} 14, \mathrm{O} 25, \mathrm{O} 32$

Anabel Marín is a researcher with the National Council for Scientific and Technological Research (CONICET), the Research Centre for Industrial Transformation (cenit) and Tres de Febrero National University (UNTREF), Argentina. a.i.marin@fund-cenit.org.ar

Lilia Stubrin is a post-doctoral fellow at the Research Centre for Industrial Transformation (CENIT), Argentina. stubrin@merit.unu.edu

María Amelia Gibbons is a research assistant with the Research Centre for Industrial Transformation (CENIT) and a teaching assistant at the University of San Andres, Argentina. amelygibb@gmail.com 


\section{I}

\section{Introduction}

This paper studies the experience of Argentine and Brazilian manufacturing firms with the accumulation of innovative capacities over the past two decades. The time frame chosen coincides with a context of economic instability and changing economic policies in both countries. This is unusual in studies of innovative capacity-building in emerging countries, which have tended to analyse long periods of continuous accumulation covering two, three or more decades. ${ }^{1}$ Such studies reveal long-term continuity on two levels. First, they usually show capacity development at the microeconomic level progressing without complications through successive stages of ever "deeper" innovation activities. Second, in the relatively few Asian countries where most of the knowledge about the long-term technological behaviour of industrial firms in emerging countries has been generated, institutional and political contexts evolved continuously and were fairly stable. Although there were changes in the main policy emphases and some political and economic shocks, crises were not far-reaching or damaging enough to destroy and disperse existing innovation capacities. Consequently, the main lines of technological development were rarely disrupted, let alone cut short or reversed.

The Latin American experience has been very different. Following a period of cumulative firmlevel capacity-building in the context of the relatively stable regimes and policies of the import substitution industrialization (ISI) period between the 1950s and 1970s, instability and fluctuations in the business cycle became recurrent. Not only have most of the region's countries been affected by acute economic and financial crises, but they have implemented far-reaching changes in the orientation of economic policy in the last few decades. Between the 1980s and 1990s, trade and finance were liberalized, State involvement in the economy was reduced, currencies appreciated and foreign investment was favoured. Thereafter, the State gradually recovered its influence on the economy and neoliberal policies began to retreat.

\footnotetext{
1 For example, Amsden (1989) in the Republic of Korea between the 1960s and 1980s; Kim (1997) on accumulation processes in the Republic of Korea; Hobday (1995) in Singapore, Taiwan Province of China and the Republic of Korea in the 20 to 30 years after the 1970s; and Mathews and Cho (2000) in their study of the development of the semiconductor industry in Asian countries.
}

These fluctuations and sudden shifts in the political and economic context are at the centre of the present study on technological capacity-building in the region, which takes manufacturing industry in Brazil and Argentina as its case studies. ${ }^{2}$ Many earlier works have characterized the innovation pattern of firms in the Latin American countries over the past few decades, including Katz (2001 and 2007), Cimoli and Katz (2003), Chudnovsky, López and Pupato (2006), Baer (1970 and 1972), Teitel and Thoumi (1987) and Erber, Guimarães y Tavares Araújo Jr. (1974). Most of these studies have analysed the generally negative repercussions of the economic reforms of the 1980s and 1990s for the innovation capacity of the manufacturing sector. ${ }^{3}$ However, this study adopts a rather different perspective. The question needs to be asked as to whether there has been any process of new innovation capacity-building in the manufacturing sector during this period of drastic economic change and macroeconomic instability (when the prevailing effect on firms' innovation capacities has been negative), what the sectoral ecology of this process is, and in what types of firms these capacities have arisen. The focus of the present research is on the new clusters of innovative firms created following the structural transformations in these countries during the 1990s. It should be pointed out that the approach is dynamic and relative, not static or absolute. The focus is not on individual cases of successful firms at a given point in time but rather on the way the technological efforts and outcomes of the main clusters of innovating firms have evolved.

The empirical analysis is based on evidence from innovation surveys. In Argentina, the surveys available cover the period from the early 1990s to the mid-2000s, while in Brazil they cover a shorter period in the 2000s. The analysis centres on firms that were in the vanguard of innovation in the countries and periods analysed. These firms were identified by taking those that claimed to have introduced a product or process innovation (or

\footnotetext{
2 A forerunner of this study is Marín and Bell (2012), centring on Argentina in 1992-2001.

${ }^{3}$ Although some innovation activities were carried out with positive results, particularly productivity increases and a narrowing of the efficiency gap with leading countries as a result of technology investment in several areas of the economy, especially industries associated with the exploitation and processing of natural resources.
} 
both) that was new to the world economy at the start of the period studied. This innovation outcome indicator, while subjective, does make it possible to identify the most significant end of the innovative firms distribution.

The evidence analysed reveals some striking (or not wholly foreseeable) facts. First, new clusters of innovative firms seem to have been emerging despite the crises and far-reaching changes in economic policy orientation that have characterized these countries in recent decades. This evidence, although preliminary, goes against a pessimistic view in the region that has mainly identified negative results. It is interesting to note, however, that these clusters of innovators are found in a small number of sectors protected by static location advantages (such as traditional sectors or those associated directly or indirectly with natural resources) and indeed some sectors favoured by public policies, such as the automotive sector, which benefits from a special protection regime in both Brazil and Argentina. Lastly, and once again challenging pessimistic notions about the innovation intensity and potential dynamism of sectors protected by static advantages (such as natural resource-linked and traditional sectors), it can be seen that firms in these sectors have been making substantial, above-average efforts to improve their innovation and technology performance, albeit from very low levels.

This research is wholly exploratory. No attempt is made to give definitive answers to all the questions raised, the intention being rather to bring new empirical evidence to the debate about the generation of innovation advantages in the region's countries. The information analysed does not cover the past few years, since innovation surveys are unavailable from 2005 onward. However, that does not take away from the main conclusions of this study, since to a large extent the phenomena identified have longer-term repercussions. Lastly, it should be stressed that the purpose of this paper is to present Argentina and Brazil as two case studies, but not to draw a comparison between them. The difficulty of comparing lies in the fact that different samples of dissimilar firms are taken for different periods, and that the indicator used to identify innovative firms, being subjective, could be influenced by national biases in the way the information employed in it is interpreted and understood.

The article is structured as follows. Section II briefly describes the context of instability in which manufacturing firms in Argentina and Brazil have operated since the relatively stable period of protection during ISI. Section III lays out the data and methodology. Section IV presents the first set of findings, identifying the sectors to which the most innovative firms belong. Section V concentrates on characterizing particularly innovative firms, identifying their origins and history and their patterns of technological behaviour. Section VI presents the implications of all this and provides some reflections based on the findings.

\section{II}

\section{The context: from protection to exposure in a setting of profound instability}

\section{The beginnings of industry: the protectionist stage}

The industrial and technological development of manufacturing in Argentina and Brazil began almost spontaneously in the late nineteenth century, when the agricultural export model was dominant in both countries. In the 1930s, however, the State began to actively promote industrialization by implementing policies to protect the domestic market (i.e., tariff barriers), creating State institutions (lending institutions and development banks) and providing infrastructure. As a result of these policies, four decades later Argentina and Brazil had developed a diversified and fairly sophisticated manufacturing sector that had begun to act as a driver of their economies.

However, industrialization in Argentina and Brazil was heavily dependent on imported inputs and capital goods from the start. This characteristic, combined with weak export growth, led to recurrent balance-of-payments deficits which fed through to the main macroeconomic variables, creating regular crises, instability and inflation.

Many authors saw the inability of the manufacturing sector to generate exportable growth, reduce import dependence and secure steady as opposed to stop-start growth as being due particularly to certain limitations and imbalances that characterized technological learning and 
industrial capacity-building (Katz, 1972, 1987, 2001 and 2007; Katz and Kosacoff, 1989 and 2000; Dahlman, 1984; Dahlman and Fonseca, 1987; United Nations, 1969). It has been argued that there was substantial growth in the manufacturing sector during the period, accompanied by steady increases in aggregate productivity and significant technological learning, particularly in some low- and medium-technology sectors (Teitel and Thoumi, 1987).

However, there were two major constraints. First, excessive vertical integration and limited specialization in engineering, combined with an abundant supply of skilled labour, resulted in an excessive domestic focus on adapting and incrementally improving technologies at the expense of investment in incorporated technological change or research and development (R\&D) aimed at significantly reducing costs and developing more "radical" innovations and new products (Teitel, 1981; López, 1996). Indeed, the evidence is that spending on R\&D, royalties, patents and franchises was low by international standards for the time (Katz, 1972). Second, inward technology transfer within sectors was very limited (Dahlman and Frischtak, 1990). In each sector, a small set of firms that had succeeded in attaining global standards of productivity through innovation efforts in engineering, quality, design and organization usually coexisted with a mass of firms characterized by low productivity, little innovation effort, obsolete equipment and products that were of low quality by international standards. It has been argued that the lack of external competition was a decisive factor in discouraging technological modernization and innovation across much of the production spectrum.

\section{Structural reforms: destruction and resurgence}

The progressive industrialization that took place, with fluctuations, throughout the twentieth century came to a sudden halt in the mid-1970s as economies were opened up and regulations and subsidies protecting the industrial sector were removed (Katz and Kosacoff, 2000). The economic instability and debt crisis of the 1980s further entrenched the process of economic and industrial stagnation. In consequence of these contextual and policy changes, manufacturing in Argentina and Brazil underwent the deepest crisis in the history of the industrial sector in the late 1970s and early 1980s. This crisis manifested itself, among other things, in the exit of firms from the market, a sharp fall-off in investment and the increasing obsolescence of capital equipment (see, among others, Katz, 2001; Kosacoff, 1996; Ferraz, Kupfer and Serrano, 1999; Baer, 2001).
In the 1990s, the liberalization and deregulation process initiated in the mid-1970s was carried further, although some novel elements also emerged: the privatization of most public-sector enterprises, price stabilization ${ }^{4}$ and currency appreciation. These elements imposed a new competition environment on industry. Studies carried out in the late 1990s and early 2000s identified the following trends as a consequence of the transformations wrought in the 1990s:

(i) A slowdown in industrial growth: in Argentina, the contribution of the industrial sector to gross domestic product (GDP) fell from 19\% in 1990 to $16 \%$ in 2000, while in Brazil industry grew at a slower rate even as it maintained its GDP share at a similar level throughout the 1990s (Barros de Castro, 2003; Ferraz, Kupfer and Iootty, 2004).

(ii) Changes at the sectoral level: some industries shrank, ${ }^{5}$ some new ones were added to the industry mix and others disappeared. Industrial and natural resource-based commodities increased their presence (Cimoli and Katz, 2003; Ferraz, Kupfer and Iootty, 2004).

(iii) Increased heterogeneity and concentration: some firms, mostly large ones and subsidiaries of multinationals, substantially raised their productivity and matched international best practices by investing in equipment and implementing organizational changes (introducing process automation, for example). However, a great many firms, particularly small and medium-sized ones (SMEs), were unable to implement these changes and disappeared, while others simply hung on, improving their productivity essentially by shedding employees (Kosacoff, 1996, 2000a and 2000b; Ferraz, Kupfer and Iootty, 2004; Katz and Bercovich, 1993).

(iv) The closing of the productivity gap: in many sectors, modernization was carried out by rationalizing costs and acquiring technologies from abroad. Tie-ups with international suppliers, licensing and online technical assistance became the preferred channels. At the same time, local equipment suppliers, engineering firms and R\&D laboratories lost ground (Katz, 2001; Ferraz, Kupfer and Haguenauer, 1996; Ferraz, Kupfer and Iootty, 2004).

(v) Transnationalization: Argentina and Brazil became the main destinations for foreign direct

\footnotetext{
${ }^{4}$ Price stabilization following enactment of the 1991 Convertibility Act in Argentina and the 1994 Real Plan in Brazil.

${ }^{5}$ In Argentina, the metallurgy and chemical industries, the two most dynamic during the ISI period, contracted in the 1990s.
} 
investment (FDI) in Latin America. In Argentina, the foreign share of total sales by the 200 largest manufacturing firms increased from 43\% in 1994 to $69 \%$ in 1998 (Kulfas, Porta and Ramos, 2002). In Brazil, multinationals increased their share of sales by the country's 300 largest firms from $14.8 \%$ to $36.4 \%$ (Rocha and Kupfer, 2002). Incoming capital was used mainly to acquire existing assets via privatization, mergers and acquisitions. Thus, the incorporation of foreign capital tended to take the form of takeovers of existing firms rather than an increase in gross fixed capital.

These characteristics arose in a context of great macroeconomic instability: periods of stabilization and growth followed by others with negative growth rates, shocks from international crises and external vulnerability. The main focus of the present analysis is on the generation of innovative capacities in the manufacturing sector from the 1990s to the mid-2000s.

\section{III}

\section{Data and methodology}

\section{Data}

The data used are from innovation surveys carried out among manufacturing firms in Argentina and Brazil. In the case of Argentina, surveys covering the periods 1992-1996 and 2002-2004 were used, while for Brazil surveys from 2000 and 2005 were analysed. Because the samples of firms altered between one survey and the next, ${ }^{6}$ the data are based on a subsample of firms featuring in every survey considered in each country. This subsample contains 608 firms in Argentina and 3,890 in Brazil.

\section{Methodology: selecting innovative firms}

The study aims to identify firms in the vanguard of innovation activity in the Argentine and Brazilian manufacturing sectors over recent decades, i.e., the subgroup of the 608 firms surveyed in Argentina and the 3,890 in Brazil that can in some way be categorized as "particularly innovative". It was not considered appropriate to employ for this purpose either of the two indicators most commonly used to measure firms' innovation capacity, namely patents and R\&D spending. - Results indicators based on patents usually have limitations, as they reflect invention rather than innovation, and because they have a strong sectoral bias (Scherer, 1983; Harabi, 1995; Levin and others, 1987). Furthermore, indicators based on patents

\footnotetext{
6 In Argentina, the 1992-1996 innovation survey covered 2,430 firms and the 2002-2004 survey 1,690. In Brazil, the 2000 and 2005 innovation surveys covered 10,328 and 12,172 firms, respectively.
}

are particularly inappropriate in contexts such as those of Argentina and Brazil, where firms rarely use patents to protect their new knowledge. This is mainly for two reasons: (i) firms are usually adopters of technologies at or close to the frontier; (ii) there is a sectoral bias in the region towards process industries, where there is usually less of a tendency to patent. In Argentina, for example, according to data from the National Institute of Statistics and Censuses (INDEC), the Secretariat of Science and Technology (SECYT) and the Economic Commission for Latin America and the Caribbean (ECLAC), between 1998 and 2001 just $10 \%$ of innovators patented (Chudnovsky, López and Pupato, 2006). In this study, the concern is to capture the general characteristics of all innovative firms, not just those that patent, meaning that indicators of this type are not wholly suitable.

- Indicators based on $\mathrm{R} \& D$ reflect the efforts made by firms to create knowledge, but do not show how effective this activity is and, more importantly in this context, tend to reflect differences in $\mathrm{R} \& \mathrm{D}$ intensity between industries rather than specific differences in innovation intensity between firms. Furthermore, these indicators tend to underestimate innovation activities closely related to production and information processing (Patel, 2000).

As innovation surveys have spread in many countries, different measures have begun to be used in the past 15 years to evaluate the innovativeness of firms. The most popular, when the aim is to measure outcomes rather than efforts, has been the percentage of sales accounted for by innovative products. In principle, this 
is a good direct measure of innovation outcomes, but it discriminates against process innovation (which is particularly important in Argentina and Brazil). This is why a different measure was chosen for the present study. Following the standard distinctions of the Oslo Manual (OECD, 1997), innovation surveys ask manufacturing firms about the degree of novelty entailed in innovations to products or processes, or both, introduced by them into the market during the survey period. When firms are asked about their innovation performance, four possible answers are available:

(i) no product (or process) innovations were introduced;

(ii) product (or process) innovations new to the firm were introduced;

(iii) product (or process) innovations new to the local economy were introduced; or

(iv) product (or process) innovations new to the world economy were introduced. ${ }^{7}$

Firms answering yes to the last of these options in the first innovation survey carried out in each country were taken to be the most innovative. An obvious constraint is that the answers are subjective. Answers by firms claiming to have introduced this category of innovation may not be a very accurate reflection of what innovations actually are "new to the world market". However, this kind of accuracy is not the main issue here, as the main concern is with the relative innovation capacity of firms within each country, rather than with the identification of global leaders. The firms surveyed have the option of selecting less novel forms of innovation, and it would seem that, at least in relative terms, this category does adequately capture the most significant end of the innovative firms distribution.

7 See the latest version of the Oslo Manual (OECD, 2005, pp. 46-47) for an explanation of these categories.
To avoid confusion, the term "significantly innovative firms" will be used in the rest of the analysis for firms replying that they had introduced product or process innovations or both that were new to the global economy. The rest will simply be termed "non-innovative firms", even though the latter group includes firms claiming to have introduced innovations that were new to the firm or the country. In the samples analysed, 68 Argentine firms (11\%) and 167 Brazilian firms (4.3\%) were found to be significantly innovative. Of these, most innovated only in products (60\% in Brazil and 67\% in Argentina). A larger share of firms in Brazil (28.1\%) than in Argentina (7.4\%) introduced only process innovations into the market. Those introducing both product and process innovations amounted to $12.6 \%$ of the total in Brazil and $25 \%$ in Argentina (see table 1).

It should be pointed out that the subjective character of the indicators used means that the findings for Argentina and Brazil ought not to be compared, as they could reflect national biases in the way the question is interpreted.

TABLE 1

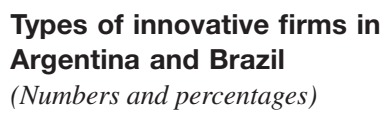

\begin{tabular}{lcc}
\hline Type of firm & Argentina & Brazil \\
\hline Non-innovative & $540(88.8)$ & $3723(95.7)$ \\
Significantly innovative & $68(11.2)$ & $167(4.3)$ \\
Process innovation only & 5 & 47 \\
Product innovation only & 46 & 99 \\
Product and process innovation & 17 & 21 \\
Total & $608(100)$ & $3890(100)$ \\
\hline
\end{tabular}

Source: prepared by the authors, on the basis of the Survey on Technological Behaviour of Argentine Industrial Firms (1992-1996) and the National Survey of Firms on Innovation, Research and Development and Information and Communication Technologies (2002-2004) in Argentina, and the Survey on Technological Innovation (PINTEC) (2000 and 2005) in Brazil.

\section{IV}

\section{Analysis I: sectoral distribution of significantly innovative firms}

This section studies the sectoral ecology of firms identified as significantly innovative. In particular, the aim is to establish whether there is a set of sectors where these firms cluster, as this will reveal areas of dynamic comparative advantages. With this in view, manufacturing sectors were classified into two groups using the three-digit International Standard Industrial Classification of All Economic Activities (ISIC): sectors including at least one significantly innovative firm, and sectors with no such firms. The latter were discarded for the purposes of the analysis. 
There are 31 sectors with at least one significantly innovative firm in Argentina and 70 in Brazil. It should be stressed, however, that the distribution of significantly innovative firms between sectors is far from homogeneous. There are sectors with many more significantly innovative firms than others (see column 3 of tables 2 and 3). To identify the sectors where significantly innovative firms cluster, the sectoral distribution of these firms was considered and sectors were classified into two groups: (i) those where the concentration of firms is equal to or greater than the median of the distribution ("sectors with clusters of significantly innovative firms"), and (ii) those where the concentration of firms is below the median of the distribution ("sectors without clusters of significantly innovative firms"). ${ }^{8}$ From here onward, firms in the first group of sectors will be referred to as "clustered innovative firms" and those in the second group of sectors as "isolated innovative firms".

Tables 2 and 3 show that clustered innovative firms are concentrated in a small set of sectors within manufacturing industry: five sectors in Argentina and seven in Brazil. These sectors account for $42 \%$ and $31 \%$ of firms of this type in Argentina and Brazil, respectively.

Some further observations should be made about the intrasectoral composition of the group of sectors

${ }^{8}$ The list of sectors without clusters of significantly innovative firms is available from the authors on request. with clusters of significantly innovative firms. Clustered innovative firms represent $18 \%$ of all firms in these sectors in Argentina and 7\% in Brazil (see the fourth column in tables 2 and 3), i.e., $82 \%$ and $93 \%$ of firms in sectors with clusters of innovative firms are not significantly innovative in Argentina and Brazil, respectively. This suggests that the selection in this study encompasses a fairly small group at the upper end of the corporate innovativeness distribution.

In terms of sectoral ecology, one important characteristic to highlight is that four of the five sectors with clustered innovative firms in Argentina and four of the seven with the same characteristics in Brazil are associated via input-output links with natural resourcebased industries $^{9}$ (see table 4). Argentina accounts for the bulk of innovative firms clustered in a group of sectors directly and indirectly linked to natural resources. The sectors directly linked to the exploitation and processing of natural resources are those that process agricultural and livestock products, while the sectors indirectly linked to the exploitation and processing of natural resources are those supplying inputs for agricultural production (fertilizer and machinery). These sectors involve the type of production activity for which Argentina has a historical competitive advantage. It should also

TABLE 2

Distribution of significantly innovative firms between sectors in Argentina (Three-digit ISIC categories)

Sector
Significantly innovative firms Significantly innovative firms in in the sector as a share of all the sector as a share of all firms significantly innovative firms in the sector

\begin{tabular}{lccc}
\hline \multicolumn{1}{c}{$(1)$} & $\begin{array}{c}(2) \\
\text { Firms } \\
\text { (number) }\end{array}$ & $\begin{array}{c}(3) \\
\text { (percentages) }\end{array}$ & $\begin{array}{c}\text { (4) } \\
\text { (percentages) }\end{array}$ \\
\hline $\begin{array}{l}\text { Clustered innovative firms } \\
\text { Manufacture of pesticides and other }\end{array}$ & 29 & 42 & 18 \\
agrochemical products & 9 & 13 & 17 \\
$\begin{array}{l}\text { Production, processing and preservation of meat, fish, } \\
\text { fruit, vegetables, oils and fats }\end{array}$ & 7 & 10 & 45 \\
Manufacture of agricultural and forestry machinery & 5 & 7 & 13 \\
Manufacture of other food products & 4 & 6 & 24 \\
Manufacture of parts and accessories for & 4 & 6 & 9 \\
motor vehicles and their engines & & 58 & 11 \\
Isolated innovative firms & 39 & 100 & \\
Total & 68 & 5 & \\
\hline
\end{tabular}

Source: prepared by the authors, on the basis of the Survey on Technological Behaviour of Argentine Industrial Firms (1992-1996). ISIC: International Standard Industrial Classification of All Economic Activities. 
TABLE 3

Distribution of significantly innovative firms between sectors in Brazil (Three-digit ISIC categories)

\begin{tabular}{|c|c|c|c|}
\hline Sector & $\begin{array}{l}\text { Firms } \\
\text { (number) }\end{array}$ & $\begin{array}{l}\text { Significantly innovative } \\
\text { firms in the sector as a } \\
\text { share of all significantly } \\
\text { innovative firms } \\
\text { (percentages) }\end{array}$ & $\begin{array}{l}\text { Significantly innovative } \\
\text { firms in the sector as a } \\
\text { share of all firms in } \\
\text { the sector } \\
\text { (percentages) }\end{array}$ \\
\hline (1) & (2) & (3) & (4) \\
\hline Clustered innovative firms & 50 & 31 & 7 \\
\hline $\begin{array}{l}\text { Manufacture of pharmaceuticals and medicinal } \\
\text { chemicals }\end{array}$ & 12 & 7 & 13 \\
\hline Manufacture of footwear and parts of footwear & 8 & 5 & 4 \\
\hline $\begin{array}{l}\text { Manufacture of parts and accessories for motor } \\
\text { vehicles and their engines }\end{array}$ & 7 & 4 & 6 \\
\hline $\begin{array}{l}\text { Manufacture of basic chemicals, fertilizers, nitrogen } \\
\text { compounds, plastics in primary forms and synthetic } \\
\text { rubber }\end{array}$ & 6 & 4 & 17 \\
\hline Manufacture of agrochemical products & 6 & 4 & 24 \\
\hline Manufacture of pumps, compressors, taps and valves & 6 & 4 & 12 \\
\hline Manufacture of plastic products & 5 & 3 & 3 \\
\hline Isolated innovative firms & 97 & 69 & 3 \\
\hline Total & 167 & 100 & 4 \\
\hline
\end{tabular}

Source: prepared by the authors, on the basis of the Survey on Technological Innovation (PINTEC) (2000 and 2005) in Brazil. ISIC: International Standard Industrial Classification of All Economic Activities.

be emphasized that a large part of the rationale for the ISI regime was to shift production specialization away from sectors of this type, in part because they were regarded as "low-technology" sectors that did little to further the incorporation of more important innovative activities within the economy (especially in the case of the industries most directly linked to natural resources).

In Brazil, sectors with clustered significantly innovative firms are more diversified between sectors connected and unconnected to activities based on the exploitation and processing of natural resources. Nonetheless, more than half of all clustered innovative firms $(60 \%)$ are involved with natural resource-based activities, typically as suppliers. Particularly prominent among sectors linked to natural resources as suppliers are those involved in the "manufacture of basic chemicals, fertilizers, nitrogen compounds, plastics in primary forms and synthetic rubber", "manufacture of agrochemical products", "manufacture of pharmaceuticals and medicinal chemicals" and "manufacture of pumps, compressors, taps and valves". It is important to clarify that while the sectors just mentioned are linked via input-output relationships to activities based on natural resource processing (see annex), it would be a mistake to think that the whole set of firms belonging to these sectors are necessarily related. For example, the "manufacture of pharmaceuticals and medicinal chemicals" sector may include both innovative firms supplying inputs to natural resource-based activities and others not connected to natural resources (such as pharmaceutical firms working in the area of human health).

Other sectors in which innovative firms cluster but which are not connected to natural resources are traditional ones such as "manufacture of footwear and parts of footwear" and "manufacture of plastic products". Clustered innovative firms that are not linked to natural resources also appear in Argentina and Brazil in sectors connected with automotive production (sectors 343 and 344). These reflect what 
TABLE 4

Classification of sectors with clusters of significantly innovative firms in Argentina and Brazil

\begin{tabular}{|c|c|c|c|}
\hline \multicolumn{3}{|c|}{ Sectors linked to natural resource-based industries } & \multirow{2}{*}{$\begin{array}{l}\text { Sectors not linked to natural } \\
\text { resource-based industries }\end{array}$} \\
\hline & Directly & Indirectly & \\
\hline Argentina & $\begin{array}{l}\text { - Production, processing and } \\
\text { preserving of meat, fish, fruit, } \\
\text { vegetables, oils and fats (151) } \\
\text { - Manufacture of other food } \\
\text { products (including bread, } \\
\text { biscuits, sugar, cocoa, tea and } \\
\text { maté, among others) (154) }\end{array}$ & $\begin{array}{l}\text { - Manufacture of pesticides } \\
\text { and other agrochemical } \\
\text { products (242) } \\
\text { - Manufacture of agricultural and } \\
\text { forestry machinery (292) }\end{array}$ & $\begin{array}{l}\text { - Manufacture of bodies } \\
\text { (coachwork) for motor vehicles; } \\
\text { manufacture of trailers and } \\
\text { semi-trailers (343) }\end{array}$ \\
\hline Brazil & & $\begin{array}{l}\text { - Manufacture of basic chemicals, } \\
\text { fertilizers, nitrogen compounds, } \\
\text { plastics in primary forms and } \\
\text { synthetic rubber (241) } \\
\text { - Manufacture of agrochemical } \\
\text { products (242) } \\
\text { - Manufacture of pharmaceuticals } \\
\text { and medicinal chemicals (245) } \\
\text { - Manufacture of pumps, } \\
\text { compressors, taps and } \\
\text { valves (291) }\end{array}$ & $\begin{array}{l}\text { - Manufacture of footwear and } \\
\text { parts of footwear (193) } \\
\text { - Manufacture of parts and } \\
\text { accessories for motor vehicles } \\
\text { and their engines (344) } \\
\text { - Manufacture of plastic } \\
\text { products (252) }\end{array}$ \\
\hline
\end{tabular}

Source: prepared by the authors, on the basis of input-output matrices for Argentina and Brazil.

remains of the flourishing automotive metallurgy industry that was nurtured during the IsI period and that since the early 1990s has been at the centre of a system of sectoral policies which includes a special trading regime between the two countries and incentives for producers.

Sectors with clusters of innovative firms were deemed more innovative, since firms of this type represent a larger percentage of all firms in these sectors than in sectors without such clusters (see the fourth column of tables 3 and 4). It must be stressed, however, that among the latter are a number of sectors where significantly innovative firms represent a larger proportion of the total than in the group of sectors where significantly innovative firms cluster. However, these sectors contain very few firms, and they appear rather to be isolated instances of innovation than areas of sectoral clustering. Some sectors with these characteristics are the "processing of nuclear fuel" sector in Argentina and Brazil (100\%), the "manufacture of insulated wire and cable" sector in
Argentina (50\%) and the "service activities incidental to oil and gas extraction excluding surveying" sector in Brazil (33\%).

In summary, it transpires that firms identified as significantly innovative in the countries analysed are clustered in a small group of sectors. In Argentina, four of the five sectors concerned are directly or indirectly linked to natural resource exploitation and processing activities. There is more variability in the case of Brazil, with none of the sectors being directly connected to natural resources as customers, but there are some sectors that are clearly associated with natural resources as suppliers and, strikingly, some traditional sectors too. Featuring in both countries is the automotive sector, which has a special protection regime. Since both natural resourcelinked activities (particularly those identified as having a direct link) and traditional ones are regarded as lowinnovation and low-value added activities, this result, taken by itself, is surprising. The next section goes into this in depth. 


\section{V}

\section{Analysis II: characterization of clustered innovative firms}

This section looks more closely at the characteristics of clustered innovative firms. The first aim is to understand the structural characteristics of these firms, such as the origin of their capital, their size and their patterns of innovation behaviour. To this end, clustered innovative firms are compared with other groups of firms such as isolated innovators, non-innovators, firms in "hightechnology" industries, ${ }^{10}$ the subsidiaries of foreign companies and the whole manufacturing establishment in general. This is followed by an exploration of the way firms' innovation behaviour changed over the period studied, with their technological behaviour being evaluated using two types of innovation effort indicators:

(i) the intensity of firms' R\&D spending (R\&D spending as a share of total sales), and

(ii) the intensity of investment in capital goods for innovation (spending on capital goods as a share of total sales).

The evidence is presented first for Argentina and then for Brazil. It is important to clarify that the data on firms' innovation behaviour in the two countries are not comparable, as they cover different years and were collected from different samples. The greatest difference is that in Brazil the averages are calculated with reference to a sample of innovative firms (firms replying that they have not innovated during the period are excluded), while in Argentina the averages are calculated from the total sample of firms interviewed, innovative or otherwise.

\section{Clustered innovative firms in Argentina}

The majority of clustered innovative firms connected to natural resources in Argentina ${ }^{11}$ are independent (52\%), while smaller proportions are subsidiaries of international companies (31\%) and local business groups (17\%) (see table 5). The composition of this set of firms differs from that of the whole set of Argentine manufacturing firms in that it includes a smaller share of independent firms ( $71 \%$ of the manufacturing sector is composed of

\footnotetext{
${ }^{10}$ Using the high-technology firms classification of the Organization for Economic Cooperation and Development (OECD).

${ }^{11}$ In Argentina, the focus is essentially on firms clustered in natural resource-linked sectors, as they account for the bulk of the total.
}

independent firms) and a larger share of subsidiaries of foreign companies and local business groups (accounting for $17 \%$ and $11 \%$ of the manufacturing total, respectively). As regards size, clustered innovative firms are larger than the mean for the manufacturing sector (see table 6 ), with $48 \%$ of clustered innovative firms having over 200 employees, as against just $39 \%$ of the whole set of manufacturing firms.

In terms of innovation behaviour, in the early 1990s clustered innovative firms in Argentina as a group made greater efforts in capital investment (1.33\%) than in R\&D $(0.10 \%)$. The pattern observed for firms of this type was also seen for the other types of firms considered (see categories 2 to 6 of table 7). However, the difference between the intensity of spending on capital goods for innovation and spending on R\&D was smaller for clustered innovative firms (taken all together) than for the other groups of firms. Another interesting point to come out of the analysis is that clustered innovative firms, together with those in high-technology sectors, are the ones that invested most in R\&D as a proportion of sales, although it might be noted that levels of R\&D spending were generally quite meagre.

When innovation behaviour is analysed separately between the different groups of clustered firms, there are found to be substantial differences between them that are worth highlighting. The innovation activity of clustered firms linked to natural resources as customers was mainly based on investment in new technologies already incorporated into capital goods. Internal R\&D spending, on the other hand, ranked among the lowest, along with that of non-innovative firms. Conversely, clustered firms indirectly linked to natural resources, along with high-technology firms, were among the types of firms investing most in R\&D in the early 1990s. They spent $0.17 \%$ of sales on R\&D activities, whereas manufacturing firms as a whole invested $0.06 \%$ of sales in the period.

As for innovative firms clustered in industries linked directly to natural resources, the pattern almost exactly matches the observations made in earlier studies of innovation activity in the 1990s. Innovation largely consisted in investments that were intensive in 
TABLE 5

Firms in Argentina by ownership type

(Numbers and percentages)

\begin{tabular}{|c|c|c|c|c|}
\hline & $\begin{array}{l}\text { Innovative firms } \\
\text { clustered in natural } \\
\text { resource-linked } \\
\text { industries }\end{array}$ & $\begin{array}{l}\text { Isolated } \\
\text { innovative firms }\end{array}$ & $\begin{array}{l}\text { Non-innovative firms } \\
\text { in all industries }\end{array}$ & $\begin{array}{c}\text { Manufacturing } \\
\text { sector total }\end{array}$ \\
\hline Local business groups & $\begin{array}{c}5 \\
(17)\end{array}$ & $\begin{array}{c}7 \\
(18)\end{array}$ & $\begin{array}{c}57 \\
(11)\end{array}$ & $\begin{array}{c}69 \\
(11)\end{array}$ \\
\hline Independent local firms & $\begin{array}{c}15 \\
(52)\end{array}$ & $\begin{array}{c}24 \\
(62)\end{array}$ & $\begin{array}{l}395 \\
(73)\end{array}$ & $\begin{array}{l}433 \\
(71)\end{array}$ \\
\hline Subsidiaries of multinationals & $\begin{array}{c}9 \\
(31)\end{array}$ & $\begin{array}{c}8 \\
(21)\end{array}$ & $\begin{array}{c}88 \\
(16)\end{array}$ & $\begin{array}{l}105 \\
(17)\end{array}$ \\
\hline Total & $29(100)$ & $39(100)$ & $540(100)$ & $608(100)$ \\
\hline
\end{tabular}

Source: prepared by the authors, on the basis of the Survey on Technological Behaviour of Argentine Industrial Firms (1992-1996) and the National Survey of Firms on Innovation, Research and Development and Information and Communication Technologies (2002-2004).

TABLE 6

Firms in Argentina by size

(Numbers and percentages)

\begin{tabular}{lcccc}
\hline & $\begin{array}{c}\text { Innovative firms } \\
\text { clustered in natural } \\
\text { resource-linked } \\
\text { industries }\end{array}$ & $\begin{array}{c}\text { Isolated innovative } \\
\text { firms }\end{array}$ & $\begin{array}{c}\text { Non-innovative firms } \\
\text { in all industries }\end{array}$ & $\begin{array}{c}\text { Manufacturing } \\
\text { sector total }\end{array}$ \\
SMEs & 15 & 27 & 327 & $(60)$ \\
Large firms & $(52)$ & $(69)$ & $(4213$ & $(61)$ \\
Total & 14 & $(31)$ & $(40)$ & $(39)$ \\
\hline
\end{tabular}

Source: prepared by the authors, on the basis of the Survey on Technological Behaviour of Argentine Industrial Firms (1992-1996) and the National Survey of Firms on Innovation, Research and Development and Information and Communication Technologies (2002-2004).

Note: small and medium-sized enterprises (SMEs) are those with 200 employees or less and large enterprises those with at least 200 employees.

TABLE 7

Argentina: innovation behaviour in the manufacturing sector, 1992

\begin{tabular}{|c|c|c|}
\hline \multirow[b]{2}{*}{ Types of firms } & R\&D intensity & Capital investment \\
\hline & \multicolumn{2}{|c|}{$\begin{array}{l}\text { Average values per firm } \\
\text { (percentages) }\end{array}$} \\
\hline 1. Innovative firms clustered in sectors: & 0.10 & 1.33 \\
\hline - directly linked to natural resources & 0.01 & 1.49 \\
\hline - indirectly linked to natural resources & 0.17 & 1.23 \\
\hline - not linked to natural resources & 0.12 & -10.16 \\
\hline 2. All other innovative firms & 0.09 & 1.97 \\
\hline 3. Firms in "high-technology" industries & 0.20 & 1.57 \\
\hline 4. Subsidiaries of foreign multinationals & 0.06 & 3.17 \\
\hline 5. Non-innovative firms & 0.01 & 1.47 \\
\hline 6. All firms & 0.06 & 1.81 \\
\hline
\end{tabular}

Source: prepared by the authors, on the basis of the Survey on Technological Behaviour of Argentine Industrial Firms (1992-1996) and the National Survey of Firms on Innovation, Research and Development and Information and Communication Technologies (2002-2004). R\&D: research and development. 
technologies already incorporated into capital goods, and production capacity was substantially enhanced as a result. However, there was virtually no sign of R\&D within firms themselves, and innovative knowledge creation capacity was hardly in evidence. In the case of firms clustered in sectors indirectly linked to natural resources, on the other hand, the findings suggest that even in the darkest periods of innovation capacity destruction in the late 1980s and early 1990s, the agricultural sector sustained a group of chemical and machinery suppliers that formed a locus of clustered innovative firms in the vanguard of innovation activity as creators of knowledge within the Argentine manufacturing sector.

It is also interesting to supplement the above data with others that reflect developments in firms' innovation behaviour during the period analysed from 1992 to 2004. Table 8 shows the findings for the indicators analysed. Over more than a decade, innovative firms clustered in sectors both directly and indirectly linked to natural resources were distinguished by the growing intensity of R\&D investment. In particular, firms in the former sectors increased the intensity of this spending almost three times as fast as the manufacturing sector average, i.e., by considerably more than non-innovative firms, which, along with this group of firms, were the ones that invested least in R\&D at the start of the period. As regards innovative firms clustered in sectors indirectly linked to natural resource-based activities, these increased the intensity of R\&D spending more quickly than other groups with a comparable intensity of $R \& D$ expenditure at the start of the period (such as firms in high-technology sectors). Clustered firms not linked to natural resources, conversely, were the only ones to show negative rates of increase in R\&D spending.

In 1992-2004, investment in capital goods for innovation fell in all the groups of firms considered. However, innovative firms clustered in sectors linked to natural resources were the ones that reduced their investment in this area least as a percentage of sales. In particular, innovative firms clustered in sectors directly linked to natural resources were alone in practically maintaining their investment in capital goods for innovation at the levels of the start of the period, even though their sales increased substantially.

In summary, taken together for the whole period analysed, the two groups of innovative firms clustered in sectors linked to activities based on the exploitation of natural resources constituted, by virtue of their relative efforts in innovation activities, an important locus of knowledge creation and usage capacity in Argentine manufacturing industry. This was a substantial and potentially important contribution, particularly at a time of great instability and upheaval like the one considered.

\section{Clustered innovative firms in Brazil}

Among clustered innovative firms in Brazil, whether or not linked to natural resource-based activities, local business groups are more heavily represented and

\begin{tabular}{|c|c|c|}
\hline \multirow[b]{2}{*}{ Types of firms } & R\&D intensity & Capital investment \\
\hline & \multicolumn{2}{|c|}{$\begin{array}{l}\text { Average values per firm } \\
\text { (percentages) }\end{array}$} \\
\hline 1. Innovative firms clustered in sectors: & 17.12 & -4.29 \\
\hline - directly linked to natural resources & 31.84 & -0.38 \\
\hline - indirectly linked to natural resources & 16.25 & -8.96 \\
\hline 2. All other innovative firms & 8.69 & -7.40 \\
\hline 3. Firms in "high-technology" industries & 10.83 & -10.59 \\
\hline 4. Subsidiaries of multinationals & 11.02 & -14.95 \\
\hline 5. Non-innovative firms & 23.41 & -7.50 \\
\hline 6. All firms & 11.57 & -7.34 \\
\hline
\end{tabular}

Source: prepared by the authors, on the basis of the Survey on Technological Behaviour of Argentine Industrial Firms (1992-1996) and the National Survey of Firms on Innovation, Research and Development and Information and Communication Technologies (2002-2004). R\&D: research and development. 
independent local firms less so than in the manufacturing sector as a whole. However, the composition of the group of innovative firms differs substantially depending on whether or not they are linked to natural resource-based activities. Among those so linked, 44\% are subsidiaries of foreign companies, a relatively strong presence, while among those that are not, foreign firms are not heavily represented (5\%). In addition, local business groups and independent local firms are more to the fore among natural resource-linked firms (45\% and 40\%, respectively) than among firms not linked to natural resource-based activities (23\% and 33\%, respectively), as can be seen in table 9 . In terms of size, clustered innovative firms are larger on average than manufacturing firms generally, isolated innovative firms and non-innovators, and $87 \%$ of innovative firms clustered in natural resource-linked industries and $100 \%$ of clustered firms not linked to natural resources have over 200 employees. Firms of this size represent $56 \%$ of all firms in the manufacturing sector (see table 10).

As regards innovation behaviour, the figures presented in table 11 show that clustered innovative firms as a group made greater $\mathrm{R} \& \mathrm{D}$ efforts relative to sales $(0.91 \%)$ than none-innovative firms $(0.36 \%)$ and the subsidiaries of multinationals $(0.79 \%)$ in 2001 , but made less of an effort than other innovative firms (1.30\%) and high-technology firms $(2.06 \%)$. It should be noted that innovative firms clustered in sectors indirectly linked to natural resource-based activities made more than twice as large an R\&D effort as clustered firms not linked to natural resource-based activities $(1.17 \%$ and $0.52 \%$, respectively). In addition, clustered innovative firms linked to natural resources as suppliers rank alongside high-technology firms as those making the greatest R\&D efforts relative to sales in the year analysed.

Observing the evolution of firms' innovation activity indicators brings some other interesting findings to light. Between 2000 and 2005, in a context where R\&D investment intensity generally declined in the Brazilian manufacturing sector, clustered innovative firms were the only ones to increase their R\&D effort year by year (see table 12). Clustered innovative firms not linked to natural resource-based activities made most progress, increasing R\&D investment intensity by $16.15 \%$. Other innovation efforts, such as the acquisition of knowledge incorporated into capital goods, were generally negative during the period analysed. However, clustered innovative firms linked to natural resources showed the smallest decline in capital investment of any type of firm (4.64\% a year).

In summary, according to the indicators analysed, clustered innovative firms in Brazil (whether or not linked to natural resource-based activities through input-output relationships) form an important locus of innovation in the Brazilian manufacturing sector. It is interesting to note that these firms stand out throughout the period studied as the ones making the greatest innovation effort (such as R\&D), of which there is little in the manufacturing sector of the region's countries.

TABLE 9

Brazil: innovative firms by ownership type

(Numbers and percentages)

\begin{tabular}{|c|c|c|c|c|c|}
\hline & $\begin{array}{l}\text { Innovative firms } \\
\text { clustered in natural } \\
\text { resource-linked } \\
\text { industries }\end{array}$ & $\begin{array}{l}\text { Clustered innovative } \\
\text { firms not linked to } \\
\text { natural resources }\end{array}$ & $\begin{array}{l}\text { Isolated } \\
\text { innovative firms }\end{array}$ & $\begin{array}{l}\text { Non-innovative } \\
\text { firms in } \\
\text { all industries }\end{array}$ & Total \\
\hline & \multicolumn{5}{|c|}{$\begin{array}{l}\text { Number of firms and proportions of column totals } \\
\text { (percentages) }\end{array}$} \\
\hline \multirow[t]{2}{*}{ Local business groups } & 7 & 9 & 29 & 486 & 522 \\
\hline & $(23)$ & $(45)$ & $(25)$ & $(13)$ & $(13)$ \\
\hline \multirow[t]{2}{*}{ Independent local firms } & 10 & 8 & 43 & 2677 & 2730 \\
\hline & (33) & $(40)$ & $(37)$ & $(72)$ & $(71)$ \\
\hline \multirow[t]{2}{*}{ Subsidiaries of multinationals } & 13 & 3 & 45 & 559 & 617 \\
\hline & $(44)$ & $(5)$ & $(38)$ & $(15)$ & (16) \\
\hline \multirow[t]{2}{*}{ Total } & 30 & 20 & 117 & 3722 & 3889 \\
\hline & $(100)$ & $(100)$ & $(100)$ & $(100)$ & $(100)$ \\
\hline
\end{tabular}

Source: prepared by the authors, on the basis of the Survey on Technological Innovation (PINTEC) (2000 and 2005). 
TABLE 10

Brazil: firms by size

(Numbers and percentages)

\begin{tabular}{|c|c|c|c|c|c|}
\hline & $\begin{array}{l}\text { Innovative firms } \\
\text { clustered in natural } \\
\text { resource-linked } \\
\text { industries }\end{array}$ & $\begin{array}{l}\text { Clustered innovative } \\
\text { firms not linked to } \\
\text { natural resources }\end{array}$ & $\begin{array}{c}\text { Isolated } \\
\text { innovative firms }\end{array}$ & $\begin{array}{l}\text { Non-innovative firms } \\
\text { in all industries }\end{array}$ & Total \\
\hline SMES & $\begin{array}{c}4 \\
(13)\end{array}$ & $\begin{array}{c}0 \\
(0)\end{array}$ & $\begin{array}{c}17 \\
(15)\end{array}$ & $\begin{array}{c}1680 \\
(45)\end{array}$ & $\begin{array}{c}1701 \\
(44)\end{array}$ \\
\hline Large firms & $\begin{array}{c}26 \\
(87)\end{array}$ & $\begin{array}{c}20 \\
(100)\end{array}$ & $\begin{array}{l}100 \\
(85)\end{array}$ & $\begin{array}{c}2042 \\
(55)\end{array}$ & $\begin{array}{c}2168 \\
(56)\end{array}$ \\
\hline Total & $30(100)$ & $20(100)$ & $117(100)$ & $3722(100)$ & 3889 (100) \\
\hline
\end{tabular}

Source: prepared by the authors, on the basis of the Survey on Technological Innovation (PINTEC) (2000 and 2005).

Note: small and medium-sized enterprises (SMEs) are those with 200 employees or less and large enterprises those with at least 200 employees.

TABLE 11

Brazil: innovation behaviour in the manufacturing sector, 2000

\begin{tabular}{|c|c|c|}
\hline \multirow[b]{2}{*}{ Types of firms } & R\&D intensity & Capital investment \\
\hline & \multicolumn{2}{|c|}{$\begin{array}{l}\text { Average values per firm } \\
\text { (percentages) }\end{array}$} \\
\hline 1. Clustered innovative firms: & 0.91 & 2.09 \\
\hline - indirectly linked to natural resources & 1.17 & 1.74 \\
\hline - not linked to natural resource-based industries & 0.52 & 2.61 \\
\hline 2. All other innovative firms & 1.30 & 3.56 \\
\hline 3. Firms in "high-technology" industries & 2.06 & 2.01 \\
\hline 4. Subsidiaries of multinationals & 0.79 & 6.03 \\
\hline 5. Non-innovative firms & 0.36 & 4.72 \\
\hline 6. All firms & 0.97 & 3.89 \\
\hline
\end{tabular}

Source: prepared by the authors, on the basis of the Survey on Technological Innovation (PINTEC) (2000 and 2005).

R\&D: research and development.

TABLE 12

Brazil: changes in innovation behaviour in the manufacturing sector, 2000-2005

Type of firm

\begin{tabular}{cc} 
R\&D intensity & \multicolumn{1}{c}{ Capital investment } \\
$\begin{array}{c}\text { Average values per firm } \\
\text { (percentages) }\end{array}$ \\
\hline 5.72 & -12.99 \\
1.50 & -4.64 \\
16.15 & -26.95 \\
-14.84 & -10.80 \\
-1.22 & -8.66 \\
-3.89 & -7.34 \\
-2.14 & -27.32 \\
-8.23 & -12.72
\end{tabular}

1. Clustered innovative firms:

- indirectly linked to natural resources

- not linked to natural resource-based industries

2. All other innovative firms

3. Firms in "high-technology" industries

4. Subsidiaries of foreign multinationals

5. Non-innovative firms

$-8.23$

$-27.32$

6. All firms

Source: prepared by the authors, on the basis of the Survey on Technological Innovation (PINTEC) (2000 and 2005).

R\&D: research and development. 


\section{VI}

\section{Discussion and final reflections}

This paper has studied the evolution of innovation capacity in the Argentine and Brazilian manufacturing sectors during a period characterized by great economic instability and changes in economic policies in both countries. Many studies have documented the destruction of firms and technological capacities that prevailed at this juncture in the region. What has been investigated here, though, is the possible resurgence of innovation capacities and their sectoral distribution. The analysis has used intertemporal data from innovation surveys in Argentina and Brazil covering the period from 1992 to 2004 in the former and from 2001 to 2005 in the latter. The findings are not definitive because they are based on analysis of such evidence as exists, which is imperfect and fragmented. Nonetheless, they provide grounds for some reflections and suggestions that are potentially important for future research. Two in particular are worth mentioning and discussing.

First, a substantial number of clustered firms are found in a small group of sectors, which were identified as being at the vanguard of innovation and which greatly increased their innovation efforts during the period under study. The evidence analysed does not suggest that these firms are world leaders, one indication of this being their low levels of R\&D expenditure, which is well below global standards; in relative terms, however, they stand out from other firms in each country, and it is thus interesting to analyse their characteristics.

Second, it should be stressed that the activities many of these innovative firms are clustered in are not the ones which would typically be expected. Firms clustered in sectors that are users of natural resources performed particularly well in Argentina, while this was true of firms clustered in traditional sectors in Brazil and of firms linked to natural resources as suppliers and clustered in sectors protected by special regimes in both countries. It is worth reflecting on the first two types: (i) firms clustered in sectors linked to natural resources, particularly as users, and (ii) firms clustered in traditional sectors.

(i) Connection to natural resources: industries connected to natural resources are usually regarded as having few technology opportunities. Since the 1950s, the development literature has argued that activities based on the exploitation and processing of natural resources have characteristics that do not make it easy for firms to exploit the advantages of technological change and add value, in comparison with other activities such as industrial manufacturing (Prebisch, 1950; Singer, 1950; Nurske, 1958). Similarly, the innovation literature has identified manufacturing industries closely linked to natural resources as having few technology opportunities; indeed, they are classified as "low-technology" industries in industrial classifications (OECD, 1997). Consequently, the typical policy recommendation for countries with a marked specialization in natural resources has been that they should foster the development of other sectors associated with greater opportunities to add value, such as those activities grouped into the so-called "high-technology" segments. Recently, though, some authors have begun to stress that sectors based on the exploitation of natural resources are intensifying their use of knowledge and thus opening up opportunities for greater learning and innovation, and thence for the development of dynamic, innovative sectors associated with them (Marín, Navas-Alemán and Pérez, in press; Pérez, 1999, 2001 and 2010; Kaplinsky and Fitter, 2004). This is largely because of fundamental changes in historical conditions, together with demand shifts and the spread of new technological paradigms. The demand for foodstuffs, raw materials and energy has intensified in recent years due to the growing globalization of markets (and the incorporation of China into the world market), with a concomitant increase in the demand for variety and quality (such as the increase in demand for gourmet foods and safer or more environmentally friendly products). This is opening up opportunities that did not formerly exist to invest in knowledge and generate variety in conjunction with natural resources. Meanwhile, the spread of new technologies such as biotechnology and nanotechnology is multiplying the potential for innovation and differentiation, just as information and communication technologies (ICTs) are favouring and facilitating the incorporation of far-flung production zones into the global market (Von Tunzelmann and Acha, 2005; Marín, Navas-Alemán and Pérez, in press). The findings presented here may be beginning to capture these phenomena. 
(ii) Traditional sectors: in the case of Brazil, areas of competitive advantage creation can also be seen in sectors that are not closely linked to natural resources but are traditional, such as the manufacture of footwear and plastic products. This may also be due to the penetration of new technologies in what are usually considered low- and medium-technology sectors (Von Tunzelmann and Acha, 2005) and to other emerging phenomena that the literature has begun to identify. Recent studies have shown, in fact, that traditional or low- to medium-technology sectors are not necessarily clusters of non-innovative firms (Kirner, Kinkel and Jaeger, 2009; HirschKreinsen, 2008). This is because products typically manufactured with old or mature technologies are beginning to be produced with technologies that are radically new or characteristic of some other industry (Kirner, Kinkel and Jaeger, 2009). The application of biotechnology to food processing is a clear example of how a sector regarded as being non-technology-intensive has begun to adopt what are identified as high-technology solutions and become increasingly dynamic. It is argued that this horizontal spread of technology between sectors will tend to blur the identification of industries with products and technologies and reduce the usefulness of certain sectoral classifications that are very widespread and heavily used.

Taken all together, these findings suggest that existing sectoral classifications may not be entirely relevant, or are not capturing recent phenomena such as intensified innovation in what are traditionally considered lowtechnology sectors, such as traditional ones and those linked directly to natural resources. They also suggest that industrial development policies that involve picking winners and are centred on identifying and strengthening isolated sectors may not be the most appropriate in the current context. On the contrary, in industrial policy terms it seems more promising to consider the interaction and interdependence between sectors (Hansen and Winther, 2010). It is known, for example, that firms in what are usually deemed low- and medium-technology industries are not only the most substantial in terms of output, employment and investment, but are the largest consumers of high-technology innovations (Robertson, Pol and Carroll, 2003). Consequently, the growth of hightechnology activities largely depends on the growth of other associated activities that are usually less intensive in R\&D (Hauknes and Knell, 2009; Robertson and Patel, 2007). This interaction needs to be considered in the region's development strategies, avoiding excessive bias towards incentives for high-technology sectors that fail to take account of their links to and interactions with other production sectors.

Lastly, some questions, limitations and suggestions for future research may be noted:

The indicators used have some limitations. First, those measuring innovation focus almost exclusively on the manufacturing sector, preventing investigation of innovation patterns in other activities that are important to the region, such as primary activities and the service sector. Again, the innovation outcome indicators available present limitations when it comes to accurately capturing the innovation dynamic in these countries. Patents are a widely used and accepted indicator in more developed countries, but they have their limits, since the bulk of the innovation process in the region's firms consists of innovations that are incremental and adaptive or have a low degree of novelty, which means that the patenting system cannot be used to protect them. Other innovation outcome indicators available, such as the one used in this study, are based on subjective answers given by the firms surveyed as to whether they innovated or not in a given period and what degree of novelty was involved. The literature recognizes that this may lead to overstatement of firms' innovativeness. Consequently, the limitations of the indicators used and of the data available require caution when it comes to interpreting the findings and making hard and fast generalizations.

Second, this paper speaks of a resurgence, but the indicators of innovation efforts such as R\&D are extremely low in some unexpected cases. It must be asked, then, whether they are low because the indicators available were unable to identify genuine innovators, or because the most significant innovators are in natural resource and traditional sectors where innovation is done differently (incremental and process innovation and engineering efforts are most important). More needs to be known in future about the characteristics of innovation in each sector, with a view to identifying indicators that serve to capture differences in the intensity of efforts and outcomes irrespective of sectoral characteristics. This will certainly enable more light to be shed on the questions raised in this study. 
ANNEX

Identifying natural resource-related sectors

Two types of industries related to the production of natural resources are identified: consumers and suppliers. The classification was carried out using indices that measure the degree of connection to activities based on the exploitation of natural resources. ${ }^{12}$ These indices use information on the value of transactions between industries drawn from each country's input-output matrix (IOM).

Because the activities in the IOM do not unequivocally match the three-digit International Standard Industrial Classification of All Economic Activities (ISIC), each sector's transactions were weighted by the sum of the value of production in the three-digit sectors corresponding to a given activity in the IOM.

The first index is the proportion of purchases from natural resource sectors made by each manufacturing industry as a share of the sector's total purchases. The larger the proportion, the greater the direct connection to natural resources.

12 On the basis of the input-output matrix (IOM), natural resource sectors are: growing of cereals, oilseeds and fodder; growing of vegetables, flowers and ornamental plants; growing of fruit and nuts; growing of industrial crops; seed production; stockbreeding and production of milk, wool and hides; farm production; agricultural services; hunting; forestry and timber extraction; fishing; oil and gas extraction and coal and uranium mining; mining of metal ores; mining of other minerals.
The following procedure was applied for each sector $j$ :

Index natural resources Cons $\cos _{j}=\frac{\operatorname{sum}\left(\operatorname{IOM}_{m=\text { natural resources }, n=j}\right)}{\operatorname{sum}\left(\operatorname{IOM}_{m, n=j}\right)}$

An analogous procedure was applied to create the second index for natural resource sector supplier industries. The greater the index value, the greater their indirect connection to natural resources:

$$
\text { Index natural resources } \operatorname{Sup}_{j}=\frac{\operatorname{sum}\left(\operatorname{IOM}_{m=\text { natural resources }, n=j}^{T}\right)}{\operatorname{sum}\left(\operatorname{IOM}_{m, n=j}^{T}\right)}
$$

The sectors identified as directly related to natural resources are those whose index values as consumers of these resources display above-average values, while sectors classified as indirectly related to natural resources are those whose index values as natural resource sector suppliers are above average. Sectors with above-average values in both groups were placed in the one for which they recorded the highest value.

\section{Bibliography}

Amsden, A.H. (1989), Asia's Next Giant: South Korea and Late Industrialization, New York, Oxford University Press.

Baer, W. (2001), The Brazilian Economy: Growth and Development, Greenwood Publishing Group.

(1972), "Import substitution and industrialization in Latin America: experiences and interpretations", Latin American Research Review, vol. 7, No. 1, Latin American Studies Association.

(1970), Siderurgia e desenvolvimento brasileiro, Rio de Janeiro, Zahar Editores.

Barros de Castro, A. (2003), "Brazil's second catch-up: characteristics and constraints", CEPAL Review, No. 80 (LC/G.2204-P), Santiago, Chile, August.

Chudnovsky, D., A. López and G. Pupato (2006), "Innovation and productivity in developing countries: a study of Argentine manufacturing firms' behavior (1992-2001)", Research Policy, vol. 35, No. 2, Amsterdam, Elsevier.

Cimoli, M. and J. Katz (2003), "Structural reforms, technological gaps and economic development: a Latin American perspective", Industrial and Corporate Change, vol. 12, No. 2, Oxford, Oxford University Press.

Dahlman, C. (1984), "Foreign technology and indigenous technological capability in Brazil", Technological Capability in the Third World, M. Fransman and K. King, London, Macmillan.
Dahlman, C. and F. Fonseca (1987), "From technological dependence to technological development: the case of Usiminas steelplant in Brazil", Technology Generation in Latin American Manufacturing Industries, J. Katz (ed.), London, Macmillan.

Dahlman, C. and C. Frischtak (1990), "National systems supporting technical advance in industry: the Brazilian experience", National Innovation Systems. A Comparative Analysis, R. Nelson (ed.), Oxford, Oxford University Press.

Erber, F., E. Guimarães and J. Tavares Araújo Jr. (1974), Absorção e criação de tecnologia na indústria de bens de capital, Rio de Janeiro, Studies and Projects Financing Entity.

Ferraz, J.C., D. Kupfer and L. Haguenauer (1996), "The competitive challenge for Brazilian industry", CEPAL Review, No. 58 (LC/G.1916-P), Santiago, Chile, April.

Ferraz, J.C., D. Kupfer and F. Serrano (1999), "Macro/micro interactions: economic and institutional uncertainties and structural change in the Brazilian industry", Oxford Development Studies, vol. 27, No. 3, Taylor \& Francis.

Ferraz, J.C., D. Kupfer and M. Iootty (2004), "Industrial competitiveness in Brazil ten years after economic liberalization", CEPAL Review, No. 82 (LC/G.2220-P), Santiago, Chile, April.

Hansen, T. and L. Winther (2010), "Innovation, regional development and relations between high- and low-tech industries", document presented at the 8th European Urban and Regional Studies Conference, Vienna. 
Harabi, N. (1995), “Appropriability of technical innovations: an empirical analysis", Research Policy, vol. 24, No. 6, Amsterdam, Elsevier.

Hauknes, J. and M. Knell (2009), "Embodied knowledge and sectoral linkages: an input-output approach to the interaction of highand low-tech industries", Research Policy, vol. 38, No. 3, Amsterdam, Elsevier.

Hirsch-Kreinsen, H. (2008), “'Low-tech' innovations”, Industry and Innovation, vol. 15, No. 1, Taylor \& Francis.

Hobday, M. (1995), Innovation in East Asia: The Challenge to Japan, Aldershot, Edward Elgar.

Kaplinsky, R. and R. Fitter (2004), "Technology and globalisation: who gains when commodities are decommodified?", International Journal of Technology and Globalization, vol. 1, No. 1, Inderscience Publishers.

Katz, J. (2007), "Cycles of creation and destruction of production capacity and the development of new export and technological capabilities in Latin America", Can Latin American Firms Compete?, T. Grosse and L. Mesquita (eds.), Oxford Scholarship Online.

(2001), "Structural reforms and technological behaviour. The sources and nature of technological change in Latin America in the 1990s", Research Policy, vol. 30, No. 1, Amsterdam, Elsevier.

(1987), "Domestic technology generation in LDCs: a review of research findings", Technology Generation in Latin American Manufacturing Industries, London, Macmillan.

(1972), "Importación de tecnología, aprendizaje local e industrialización dependiente", Documento de trabajo, Buenos Aires, Instituto Torcuato di Tella.

Katz, J. and N.A. Bercovich (1993), "National systems of innovation supporting technical advance in industry: the case of Argentina", National Innovation Systems: A Comparative Analysis, R.R. Nelson (ed.), New York, Oxford University Press.

Katz, J. and B. Kosacoff (2000), "Import-substituting industrialisation in Argentina, 1940-1980: its achievements and shortcomings", Industrialisation and the State in Latin-America: the Post War Years, E. Cárdenas, J.A. Ocampo and R. Thorp (eds.), Basingstoke.

(1989), "El proceso de industrialización en la Argentina: Evolución, retroceso y prospectiva", Buenos Aires, Centro Editor de América Latina.

Kim, L. (1997), Imitation to Innovation: The Dynamics of Korea's Technological Learning, Boston, Massachusetts, Harvard Business School Press.

Kirner, E., S. Kinkel and A. Jaeger (2009), "Innovation paths and the innovation performance of low-technology firms - An empirical analysis of German industry", Research Policy, vol. 38, No. 3, Amsterdam, Elsevier.

Kosacoff, B. (2000a), Corporate Strategies under Structural Adjustment in Argentina: Responses by Industrial Firms to a New Set of Uncertainties, Basingstoke, Macmillan.

(2000b), El desempeño industrial argentino más allá de la sustitución de importaciones, Buenos Aires, ECLAC office in Buenos Aires.

(1996), "Estrategias empresariales en la transformación industrial argentina", Working Paper, No. 67 (LC/ BUE/L.150), Santiago, Chile, Economic Commission for Latin America and the Caribbean (ECLAC).

Kulfas, M., F. Porta and A. Ramos (2002), "Inversión extranjera y empresas transnacionales en la economía argentina", Estudios y Perspectivas series, No. 10 (LC/L.1766-P), Buenos Aires, ECLAC office in Buenos Aires. United Nations publication, Sales No. S.02.II.G.80.

Levin, R.C. and others (1987), "Appropriating the returns from industrial research and development", Brookings Papers on Economic Activity, vol. 18, No. 3, Washington, D.C., The Brookings Institution.
López, A. (1996), "Las ideas evolucionistas en economía: Una visión de conjunto", Revista Buenos Aires. Pensamiento Económico, No. 1, Buenos Aires.

Marín, A. and M. Bell (2012), "Argentina”, Innovative Firms in Emerging Market Countries, E. Amann and J. Cantwell (eds.), Oxford, Oxford University Press.

Marín A., L. Navas-Alemán and C. Pérez (in press), "Natural Resource Industries as a Platform for the Development of Knowledge Instensive Industries".

Mathews, J. and D.-S. Cho (2000), Tiger Technology: The Creation of a Semiconductor Industry in East Asia, Cambridge, Cambridge University Press.

Nurske, R. (1958), "Trade fluctuations and buffer policies of lowincome countries", Kyklos, vol. 11, No. 2, Wiley.

OECD (Organization for Economic Cooperation and Development) (2005), Oslo Manual: Guidelines for Collecting and Interpreting Innovation, Paris.

(1997), "Revision of the high-technology sector and product classification", OECD Science, Technology and Industry Working Papers, No. 1997/02, Paris.

Patel, P. (2000), "Technological indicators of performance", From Knowledge Management to Strategic Competence: Measuring Technological, Market and Organisational Innovation, J. Tidd (ed.), London, Imperial College Press.

Pérez, C. (2010), "Technological dynamism and social inclusion in Latin America: a resource-based production development strategy", CEPAL Review, No. 100 (LC/G.2442-P), Santiago, Chile, April.

(2001), "Technological change and opportunities for development as a moving target", CEPAL Review, No. 75 (LC/G.2150-P), Santiago, Chile, December.

(1999), "Cambio de patrón tecnológico y oportunidades para el desarrollo sustentable", Colección Ideas para el Diálogo, No. 3, Caracas, Biblioteca Nacional de Venezuela.

Prebisch, R. (1950), The Economic Development of Latin America and Its Principal Problems (E/CN.12/89), New York, United Nations.

Robertson, P.L., E. Pol and P. Carroll (2003), "Receptive capacity of established industries as a limiting factor in the economy's rate of innovation", Industry and Innovation, vol. 10, No. 4, Taylor \& Francis.

Robertson, P.L. and P.R. Patel (2007), "New wine in old bottles technological diffusion in developed economies", Research Policy, vol. 36, No. 5, Amsterdam, Elsevier.

Rocha, F. and D. Kupfer (2002), "Structural changes and specialization in Brazilian industry: the evolution of leading companies and the M\&A process", The Developing Economies, vol. 40, No. 4, Tokyo, Institute of Developing Economies, December.

Scherer, F.M. (1983), “The propensity to patent", International Journal of Industrial Organization, vol. 1, No. 1, Amsterdam, Elsevier.

Singer, H. (1950), "The distribution of gains between investing and borrowing countries", American Economic Review, vol. 40, No. 2, Nashville, Tennessee, American Economic Association.

Teitel, S. (1981), "Towards an understanding of technical change in semi-industrialized countries", Research Policy, vol. 10, No. 2, Amsterdam, Elsevier.

Teitel, S. and F. Thoumi (1987), "De la sustitución de importaciones a las exportaciones: La experiencia de las exportaciones manufactureras de la Argentina y el Brasil", Desarrollo Económico, vol. 27, No. 105, Buenos Aires, Institute of Economic and Social Development.

United Nations (1969), "The manufacture of machine tools in Brazil", Development of Metalworking Industries in Developing Countries, New York.

Von Tunzelmann, N. and V. Acha (2005), "Innovation in 'low-tech' industries", The Oxford Handbook of Innovation, J. Fageberg, D. Mowery and R. Nelson (eds.), Oxford, Oxford University Press. 